\title{
The Analysis of Brand Awareness Measurement in Amil Zakat Institution of Nu Care Lazisnu Bandung
}

\author{
Linda Mauliani Purnamasari ${ }^{1, *}$ Ratih Hurriyati ${ }^{2}$ Puspo Dewi Dirgantari ${ }^{3}$ \\ ${ }^{1}$ Universitas Pendidikan Indonesia \\ ${ }^{2}$ Universitas Pendidikan Indonesia \\ *Corresponding author.Email: gusti.anggara@yahoo.co.id
}

\begin{abstract}
Amil zakat institutions must continue to compete positively by maintaining a positive image or making people aware that this institution can manage ZIS funds properly. To be known and remembered by the public, an institution must create and increase brand awareness. The method used in this research is a descriptive method to describe the brand awareness of NU CARE-LAZISNU Bandung with a sample of 100 respondents from Bandung. In this study, researchers distributed questionnaires to respondents. Based on the analysis of brand awareness measurement in NU CARE-LAZISNU, Bandung has not been able to occupy the top of mind and brand recall because the value obtained is minimal. NU CARE-LAZISNU Bandung is at the brand recognition and unaware stage. NU CARE-LAZISNU Bandung's marketing strategy can carry out by using social media because the community is now inseparable from social media.
\end{abstract}

Keywords: brand awareness, marketing, measurement.

\section{INTRODUCTION}

Based on data from the Central Bureau of Statistics (BPS) Population Census Results in 2010 [1], it was found that the population of Muslims is $87.18 \%$ of Indonesia's total population. From these data, it can be assumed that the Muslim population can optimize the potential of existing zakat to help the government reduce poverty in Indonesia.

The results of research conducted by [2] reported that Indonesia has a potential zakat fund of Rp 217 trillion / year [3]. Meanwhile, according to reference [2], the potential for zakat in Bandung is Rp 2 trillion / year.

The acceptance of zakat in Bandung City compared to the potential for zakat in Bandung City during the last 3 (three) years in 2016-2018 is less than 3\% per year from the existing zakat potential. Even though the government has issued a new regulation regarding the payment of zakat through amil zakat agency or amil zakat institutions, it can be used to deduce income tax payments. This rule is expected to increase the community's interest in paying zakat, but this has not yet run optimally.

This zakat potential is in a considerable amount so that it has to be managed well by the existing amil zakat institutions. It means that the existing amil zakat institutions must work even more challenging. Amil zakat institutions need to increase their accountability and professionalism in managing ZIS funds.

One of the amil zakat, infaq, and sadaqah institutions or LAZIS in Indonesia is NU CARE LAZISNU. NU CARE LAZISNU is a non-profit institution owned by the Nahdlatul Ulama (NU) association, aiming to help the welfare of the people and lifts social dignity by utilizing Zakat, Infaq, Sadaqah, and Wakaf funds (ZISWAF). NU CARE-LAZISNU is a rebranding and/or entry point for the global community to know the Nahdlatul Ulama Amil Zakat, Infaq Sadaqah Institution (LAZISNU). NU CARE LAZISNU Bandung as one of the network branches of NU CARE LAZISNU. 
The achievement of NU CARE LAZISNU Bandung's zakat acceptance compared to the NU CARE LAZISNU Center's target for the last 3 (three) years is less than $5 \%$ per year. This shows that NU CARE LAZISNU Bandung is not optimal in collecting zakat.

In 2018 there were 13 official LAZs in Bandung. The party that manages this institution is the private party which has been authorized by the government according to Law No. 23 of 2011. As for LAZ that has been registered and operates in Bandung there are 13 (thirteen) LAZ, as: Dompet Peduli Ummat Daarut Tauhid; Dompet Dhuafa Republika Bandung; Lazis MU; Pusat Zakat Umat; Rumah Zakat; Rumah Amal Salman; Inisiatif Zakat Indonesia; NU CARELAZISNU; Zakatku Bakti Persada; Indonesia Berbagi; Panti Yatim Indonesia; Sinergi Foundation; and Yatim Mandiri [4].

Since amil zakat institutions are many, this has become competitive for its managers. Amil zakat institutions must continue to compete positively by maintaining a positive image or making people aware that this institution can manage ZIS funds properly. This was done to win donors' hearts to carry out the obligation to donate or entrust their ZIS funds at the amil zakat institutions concerned.

To be known and remembered by the public, an institution must create and increase its brand awareness. Brand awareness describes a brand's presence in the minds of consumers that will affect consumers' perceptions and behavior. According to reference [5], by creating brand awareness, people will bring back memories of the brand when their category needs arise.

Based on previous researches, it is known that brand awareness can affect the quality of perception and purchase intention of consumers [6-8]. Brand awareness improves customer satisfaction and trust [9]. Brand awareness will also affect organizational performance [10].

According to reference [11], brand equity is a set of brand assets and liabilities associated with a brand, name, and symbol that add or subtract the value provided by a good or service to a company or its customers. Another study by reference [12] defines brand equity as the added value given to products and services. This value can be reflected in how a consumer thinks, feels, and acts on the brand, price, market share, and profitability of the company.

According to reference [11], "Brand awareness is the power of the existence of a brand in the customer's mind. That strength is shown by customers' ability to recognize and remember a brand". According to reference [13], "brand awareness is the ability of a brand to appear in consumers' minds when they are thinking about certain product categories and how easily the name is raised". Brand awareness is a pri-mary dimension of brand equity. From the consumer's perspective, a brand has no equity until the con-sumer is aware of its existence.

\section{METHODS}

The object of this research is the brand awareness of NU CARE-LAZISNU Bandung. The method used in this research is descriptive to describe the brand awareness of NU CARE-LAZISNU Bandung. In this study, researchers distributed questionnaires to respondents.

According to reference [14], the level of brand awareness can be explained as follows: 1) Un-aware of the Brand is the lowest level in the brand awareness pyramid, where consumers are not aware of the existence of a brand; 2) Brand Recognition is a minimum level of brand awareness, where the introduction of a brand reappears after aided recall; 3) Brand Recall is a reminder of the brand without assistance; 4) Top of Mind is a brand that consumers first mention or that first appears in the minds of consumers. In other words, these brands are the leading brands of various brands in the minds of consumers.

Population in Bandung City is the population in this study. Based on the Bandung central bureau of statistics (BPS) [2], the population in 2019 was $2,507,888$ people. The random sampling implemented the Slovin formula with an error rate of $10 \%$ so that the samples used in this study are 100 people. The researchers distributed questionnaires via google form to 100 respondents who were Muslim residents of Bandung City.

\section{RESULTS AND DISCUSSION}

\subsection{Top of mind analysis}

Top of mind describes the brand that respondents first remember when asked about a product category. This top of mind is a single response question, meaning that a respondent may only give one answer to this question. In this study, 100 people are used as respondents, and of the 100 respondents obtained, $48 \%$ (48 respondents) mentioned Rumah Zakat as the first brand they remember the most, 27\% (27 respondents) mentioned Dompet Dhuafa, which they remembered the most, 15\% (15 respondents) mentioned the DPU DT they remembered the most, 3\% (3 respondents) mentioned the Panti Yatim Indonesia they remembered the most, 3\% (3 respondents) mentioned the Rumah Amal Salman they remembered the most, 2\% (2 respondents) mentioned Sinergi Umat they remember the most, and 2\% (2 respondents) mention NU CARELAZISNU they remember the most. Table 1 . Show top of mind-brand awareness. 
Table 1. Top of Mind-Brand Awarness

\begin{tabular}{|l|l|l|}
\hline Amil Zakat Institutions & Frequency & Percentage \\
\hline Rumah Zakat & 48 & $48 \%$ \\
\hline Dompet Dhuafa & 27 & $27 \%$ \\
\hline DPU DT & 15 & $15 \%$ \\
\hline Panti Yatim Indonesia & 3 & $3 \%$ \\
\hline Rumah Amal Salman & 3 & $3 \%$ \\
\hline Sinergi Umat & 2 & $2 \%$ \\
\hline NU CARE-LAZISNU & 2 & $2 \%$ \\
\hline Total & 100 & $100 \%$ \\
\hline
\end{tabular}

Primary data (2020)

Based on Table 1 it can be seen that NU CARELAZISNU does not yet include the top of mind. This can be seen from the respondents' answers to questions about zakat institutions that respondents most remember.

\subsection{Brand recall analysis}

Brand recall reflects what respondents remember brands after mentioning the brand that is first mentioned. Brand Recall is multi-response questions that produce unaided questions. In the Brand Recall analysis, the researchers asked respondents to answer question number two by stating three zakat institutions other than those already mentioned in the first question. Table 2. Show the result brand recall-brand awareness

Table 2. Brand Recall-Awarness

\begin{tabular}{|l|l|l|}
\hline \multicolumn{1}{|c|}{$\begin{array}{c}\text { Amil Zakat } \\
\text { Instutions }\end{array}$} & \multicolumn{1}{|c|}{ Frequency } & Percentage \\
\hline Rumah Zakat & 135 & $45 \%$ \\
\hline Dompet Dhuafa & 108 & $36 \%$ \\
\hline DPU DT Amal & 24 & $8 \%$ \\
\hline $\begin{array}{l}\text { Rumah Yatim } \\
\text { Salman }\end{array}$ & 12 & $4 \%$ \\
\hline $\begin{array}{l}\text { Panti CARE- } \\
\text { Indonesia }\end{array}$ & 3 & $4 \%$ \\
\hline Sinergi Umat & 3 & $1 \%$ \\
\hline IZI NU & $1 \%$ \\
\hline $\begin{array}{l}\text { NAZISNU Total primary data }(2020) \\
\text { Source : }\end{array}$ & $100 \%$ \\
\hline
\end{tabular}

Based on Table 2, it can be seen that NU CARELAZISNU has included brand recall with a value of $1 \%$, and the remaining $99 \%$ mentioned by respondents are Rumah Zakat, Dompet Dhuafa, DPU DT, Rumah Amal Salman, Panti Yatim Indonesia, Sinergi Umat, and IZI.

\subsection{Brand recognition analysis}

Brand recognition or the introduction of brand awareness is the measurement of respondent's brand awareness where awareness is measured by assisting. The questions raised are assisted by mentioning the characteristics of these brand products (aided questions). In this brand recognition analysis, the researchers tried to remind respondents by mentioning NU CARE-
LAZISNU on the questionnaire. The results are shown in Table 3 below:

Table 3. Brand Recognition \& Unware Brand-Brand Awarness

\begin{tabular}{|l|l|l|}
\hline \multicolumn{1}{|c|}{ Answer } & Frequency & Percentage \\
\hline $\begin{array}{l}\text { Yes, I interceded and wrote down } \\
\text { questions 1 and 2 }\end{array}$ & 5 & $5 \%$ \\
\hline $\begin{array}{l}\text { Yes, I know them after filling in } \\
\text { this question }\end{array}$ & 55 & $55 \%$ \\
\hline Not familiar at all & 40 & $40 \%$ \\
\hline Total & 100 & $100 \%$ \\
\hline Source : primary data (2020)
\end{tabular}

The results of the study above show that brand recognition was analyzed based on the percentage of respondents who answered with the choice of answers item (a) from table 6 known that respondents who answered item (a) were five people or $5 \%$, respondents who answered with choice of items (b), from table 6 it is known that the respondents who answered item (b) were 55 people or $55 \%$ of respondents. Thus $55 \%$ of 100 respondents must be reminded in the introduction of brand awareness. In other words, as much as $55 \%$ of respondents must be reminded of the existence of $\mathrm{NU}$ CARE-LAZISNU.

\subsection{Unware brand analysis}

NU CARE-LAZISNU Amil Zakat Institution is one of the amil zakat institutions that are not yet well-known and are not well remembered by the public. This is evident from the $55 \%$ of respondents who must be reminded of NU CARE-LAZISNU and $40 \%$ of respondents who do not know NU CARE-LAZISNU.

\subsection{Media information source}

Based on 100 respondents taken during the study, the distribution of media information sources obtained by respondents to determine the existence of amil zakat institutions is shown in the Table 4.

Table 4. Media Source

\begin{tabular}{|l|l|l|}
\hline \multicolumn{1}{|c|}{ Media } & \multicolumn{1}{c|}{ Frequency } & \multicolumn{1}{c|}{ Percentage } \\
\hline Radio and Television & 7 & $7 \%$ \\
\hline Social Media & 61 & $61 \%$ \\
\hline Billboard & 22 & $22 \%$ \\
\hline Friends/family & 10 & $10 \%$ \\
\hline Total & 100 & $100 \%$ \\
\hline
\end{tabular}

Source : primary data (2020)

Based on table 4 , it can be seen that the majority of respondents knowing or recognizing the existence of zakat institutions that are with the help of social media. This is due to technological advancements in this era, so that social media has a vital role in the promotion event. According to reference [15], the strategy of utilizing social media to introduce consumers or the public to a brand, product, or service from a business company or other agency. 
This is in line with the research results that internet marketing or social media marketing will improve brand awareness [16,17].

\section{CONCLUSION}

Based on the analysis of brand awareness measurement in NU CARE-LAZISNU, it has not been able to occupy the top of mind and brand recall because the value obtained is minimal. NU CARE-LAZISNU Bandung is at the brand recognition and unaware stage. The marketing strategy that NU CARE-LAZISNU can carry out is social media because the community now can not be separated from social media.

\section{ACKNOWLEDGMENT}

Thanks to the management science doctoral program School of Postgraduate Studies of Universitas Pendidikan Indonesia and all those who helped complete this research

\section{REFERENCES}

[1] Penduduk Indonesia Hasil SP 2010. BPS Kota Bandung. May 30, 2020. [Online]. Avaible : https://bandungkota.bps.go.id/.

[2] Outlook Zakat Indonesia 2016. Pusat Kajian Strategis BAZNAS. 2020. [Online]. Avaible: https://puskasbaznas.com/

[3] N. Huda, D. Anggraini, K. M. Ali, Y. Mardoni, and N. Rini, "Prioritas solusi permasalahan pengelolaan zakat dengan metode ahp (studi di Banten dan Kalimantan Selatan)," Al-Iqtishad J. Islam. Econ., 2015.

[4] Ministry of Religious Affairs is Requested to Improve Public Service Through Digital. Jabarprov.go.id. January 3, 2018. [Online]. Avaible:

https://www.jabarprov.go.id/En/index.php/news/50 34/Ministry_of_Religious_Affairs_is_Requested_to _Improve_Public_Service_Through_Digital.

[5] D. Lubis, "Pengaruh brand characteristic terhadap kepercayaan dan niat beli konsumen serta dampaknya pada loyalitas konsumen," JEB., vol. 5. no, 1, 2011.

[6] Rahmawan, Ginanjar, and Suwitho, "The influence of brand image, brand awareness, perceived quality on school shoes purchase intention," Proc. 1st International Conference on Business \& Social Sciences (ICOBUSS)., 2020.

[7] Padhy, S. Kumar, R.K. Sawlikar, "The role of brand equity and brand awareness on consumers' purchase intention," International J. Business and Management Invention (IJBMI), vol. 7, no. 1, pp. 12-16, 2018

[8] Lesmana, Rosa, A.S. Widodo, and N. Sunardi, "The formation of customer loyalty from brand awareness and perceived quality through brand equity of xiaomi smartphone users in south tangerang," J. Pemasaran Kompetitif., vol. 4, no. 1, pp. 1-12, 2020.

[9] [2] Ö. Sürücü, Y. Öztürk, F. Okumus, and A. Bilgihan, "Brand awareness, image, physical quality and employee behavior as building blocks of customer-based brand equity: Consequences in the hotel context," J. Hosp. Tour. Manag., 2019.

[10]P. Foroudi, "Influence of brand signature, brand awareness, brand attitude, brand reputation on hotel industry's brand performance," Int. J. Hosp. Manag., 2019.

[11]D. a Aaker, "Managing Brand Equity," J. Mark., 1991.

[12]P. Kotler and K. L. Keller, Manajemen pemasaran Jilid 1. 2009.

[13] A. Shimp, Terence, Periklanan Promosi \& Aspek Tambahan Komunikasi Pemasaran Terpadu, Jilid I. 5 Ed, Jakarta :Erlangga, 2003.

[14] Durianto, Darmadi, Sugiarto, L.J. Budiman, Brand Equity Ten: Strategi Memimpin Pasar. Jakarta : Gramedia Pustaka Utama, 2004.

[15] Pritama, A. Dwi, M.A.W Prasetyo, P.P Galih, "Analisis brand awareness official video profil STMIK AMIKOM Purwokerto 2017 di Media Youtube," J. Pro Bisnis., vol. 12, no. 1, pp. 1-1, 2019.

[16] A. Dilham, F. R. Sofiyah, and I. Muda, "The internet marketing effect on the customer loyalty level with brand awareness as intervening variables,” Int. J. Civ. Eng. Technol., 2018.

[17] Y. Bilgin, "The effect of social media marketing activities on brand awareness, brand image and brand loyalty," Bus. Manag. Stud. An Int. J., 2018 Retailing,

2017. 